\title{
Analysis on the Influence of Female Characters in Disney Films
}

\author{
$\mathrm{Mo} \mathrm{Xu^{1,* }}$ \\ ${ }^{1}$ Culver Academies, Culver, Indiana, 46511America \\ *Corresponding author. Email: 651140@culver.org
}

\begin{abstract}
Walt Disney Studios is the biggest film production company at present. Disney has been established for over 80 years, during which period it has played a vital role in social impact on women. Disney undergoes several significant changes when it comes to feminism depiction in their movies. Subtle feminism can be seen in influential films such as Tangled, Mulan and Frozen. In this article, the author will analyze the female roles in Disney films through different eras, aiming to explore the various styles of Disney's feminist films and its social influence, as well as the popular expectations led by different roles. What is more, the author will discuss the way they made effects on society's gender roles. Additionally, the subtle feminist messages in specific highly influential movies such as Tangled, Mulan, and Frozen will also be released. In conclusion, throughout the decades, Disney films and characters have produced different impacts on society's female roles and stereotypes, which is worth further study for the development of the film industry, even the whole society.
\end{abstract}

Keywords: Disney animation, Walt Disney, Animation, Tangled, Sleeping Beauty, Mulan, Feminism, Frozen

\section{INTRODUCTION}

Disney is one of the largest entertainment companies in the world, and it owns lots of unforgettable films and TV channels. With parks and fantasy lands around the globe, Disney has become an irreplaceable establishment that makes the world a more magical place. However, Disney has also utilized the characters in their films to make an impact on society throughout the decades. One of the most notable things would be the immense influence that Disney's female characters have created through several aspects. This article focuses on analyzing different styles of feminist movies throughout different eras of Disney, and how they have exerted effects on gender roles. The author will also go in depth on several largely influential films, such as The Little Mermaid, Mulan, and Raya and the Last Dragon, in order to release subtle hints of feminism or anti-feminism in the films and their impacts on the audience. By analyzing the female roles in different eras, the author aims to explore the various styles of Disney's feminist films as well as the ways that different roles influence social views and popular expectations.

\section{DISNEY'S ANIMATED FEMALE CHARACTERS IN DIFFERENT ERAS}

Disney was founded in 1923 by Walt and Roy Disney, but it did not get its first big hit until 1937 with the successful production of Snow White and the Seven Dwarf, thus, calling forth the Golden Age. The next decade (1950-1959) is known as the Silver Age or the Restoration Age. Walt Disney's death marked the end of the Silver Age and brought forth the Bronze Age (19701988). Struggling to find its way without Walt, this was a period of decline for Disney, filled with trial and error films. Thankfully, the Disney Renaissance age came forth from 1989 to 1999. The Post Renaissance Era films, from 2000 to 2009 , had no common theme with each other and produced average animation films that never really became wildly popular. The last era is the Revival Era of the 21st Century. Disney started picking itself up and released several high-budget films such as Frozen, Tangled, and Wreck-It Ralph that stole the hearts of audiences around the world [1].

In the film Snow White and the Seven Dwarfs, feminism is basically nonexistent. Snow White is portrayed as a fragile, ideally beautiful, polite young 
lady, which is what society expected of a woman. She is one of the stereotypical, useless and helpless princess, who wears a pretty princess dress, has a waist smaller than her head, and sweeps and cleans. Snow White is a damsel in distress, who falls heads over heels for her prince in shining armor. Disney's Wartime era featured no princesses nor lead female roles. Additionally, the Silver Age, although filled with interesting female lead characters, showed no apparent message towards feminism. Iconic films and princesses, such as Cinderella and Sleeping Beauty, follow an almost identical path as Snow White. Skipping the dull and disappointing Bronze Age, it comes to the celebrated Renaissance Era, where Disney started to focus on feminism as well as independence and power. Although people still see Ariel from The Little Mermaid as a picture-perfect princess, she stands out through not only her unique costume but also her desire to be her own person [2]. Ariel is defiant towards her father and has big dreams, and she finally accomplishes her dreams. She sings Part of That World to express her independent desire to leave her kingdom and explore the human world. Prominent critic Roger Ebert praised Ariel as an active and rebellious heroine. He admires that "Ariel is a fully realized female character who thinks and acts independently, even rebelliously, instead of hanging around passively while the fates decide her destiny" [3]. The next two major films, Pocahontas and Beauty and The Beast are also similar. It can be seen that Disney further crawls out of its shell in the 1998 film, Mulan. Mulan is an independent and strong girl. However, she physically breaks stereotypes as she cuts off her hair, puts on a suit of armor, and goes to war. Furthermore, Mulan is the first female character who does not openly seek out a male partner [2]. Mulan's masculine clothing, personality, and actions as well as her several female traits, mix together to create a unique and unprecedented feminist character. The Post Renaissance Era once again returned to a neutral tone with less popular films that had no gender-related themes. Finally, the Revival Era of the 21st century arrives with Tangled and The Princess and The Frog, without representing a big leap from the Renaissance films. One of the pinnacles of Disney feminism began in 2010's renowned Brave and the feminist message grew even bigger in 2013's Disney Frozen, featuring two leading female roles for the first time in history [2]. Disney films have already become a well-established symbol for feminism and empowerment. Nevertheless, Disney's latest princess movie, Raya and the Last Dragon, might be the most powerful movie, as it creates an entire world full of powerful women and centers its story on relationships between multiple female characters. Raya's world is filled with dominant women soldiers, leaders, queens, and dragons. The physical appearance of characters smashes through stereotypes, with characters of different styles and clothing. For example, Raya and Namarri both sport simple pants and belts, with Namarri styling an intimidating short side cut. On the contrary, there are also characters, such as Virana who wears elegant gowns. Disney finally strayed away from their generic, stereotypical female face as Raya and the Last Dragon casts characters with unique features and bodies. Through decades of evolution, Disney's female characters have changed a lot, from the type of tradition to the type without specific features, which also reflects the change of the society.

\section{DISNEY CHARACTERS AND GENDER EQUALITY}

\subsection{Stereotypes of Disney Female Characters}

The influence of female characters in Disney movies on society cannot be ignored, especially female stereotypes. People will always subconsciously regard the characteristics of the characters as the criteria for judging real women. For the appearance, princess is always with big eyes while witch is ugly. For the gender roles, man is taking the position of dominating while woman takes the burden as housewife.

In earlier films such as Snow White, Cinderella, and Aurora, the characters strongly reinforced the unfair expectations and stereotypes for females. During the time's release for these films, women and girls were still bound to the stereotype of homemakers, with only 39 percent of American women working by the end of the Pre-Transition period [4]. These young, pretty, sweet-natured princesses portray the societal views of what was expected of females and their gender roles [5]. All of them are given tasks such as cleaning, cooking, and being a motherly figure. Aurora, from Sleeping Beauty, plays a housewife role for her household, often seen happily sweeping and wiping. This contentment once again speaks to the audience, declaring "This is what you are all supposed to do". In Snow White and the Seven Dwarfs, even when Snow White finds the dwarfs, her first instinct is to clean and care for them. All three princesses also required the heroism of the prince other than the potential heroine-and unfortunately, contributed to the gender stereotypes of the time period rather than progressing the women's movement toward equality [4]. Furthermore, their physical appearances were also designed to fortify the idea of a "perfect" woman. Each character has stereotypical features such as large eyes, pale skin, an impossibly thin waist, button nose, and overall slim figure, setting an impossible expectation for young girls around the world. Disney restates these expectations by making their villains have "ugly" traits. For example, The Little Mermaid's main antagonist, Ursula, is heavily set and the two mean sisters of Cinderella have big cheeks, noses, and large bodies. These features negatively impacted the expectations for women at that time, and reinforced the unfair demands society had for 
women. Absolutely, this stereotypical depiction of "beautiful" women will continue to be seen in Disney films until the late 1990s, and even reappear in several modern films such as Frozen and Tangled.

\subsection{The Impact of Stereotypes of Female in Disney Films}

Film is a part of everyday life and the industry is developing every single day. Society is reflected in movies and in turn movies influence society by changes in representations, challenging the audience's morals, and transforming viewers' opinions [6]". Films have more impact on society and people than anything else, which has been lasted for many decades.

\subsubsection{Impact on females in real life}

One of the most notable effects of stereotypes portrayed in films is the stereotype threat. Studied by psychologists and researchers and first introduced by Steele [7], stereotype threat refers to being at risk of confirming, as a self-characteristic, a negative stereotype about one's social group [8]. It is found that women solved fewer math problems when they were primed with a negative group-based stereotype, relative to those who received a positive or no stereotype [9]. Such an effect works the same way in stereotypical films that show submissive women. Children will subconsciously start to believe that they are inferior and less capable to men, so these demeaning films will cause stereotype threat in these children, causing them not to be able to perform at their best and lose confidence.

Furthermore, Disney itself has played an active role in reinforcing harmful stereotypes, which has produced performance, mental, and physical effects on children and teens. During childhood, just one year of exposure to stereotypical Disney films can result in an exhibition of more female gender-stereotypical behaviors, even after taking into account initial levels of stereotypical behavior. The results suggest that engagement with princess culture, including media, can influence gender stereotypes and may contribute to a hyper feminine culture [10]. Stereotypical Disney princess films have negative impacts on young girls at present. A study that published in Child Development, involved 198 preschoolers and assessed how much they interacted with Disney Princess culture. For both boys and girls, more interactions with the princesses predicted more female gender-stereotypical behavior a year later. Gendered behavior can become problematic when girls start to avoid important learning experiences that are not perceived as feminine or believe their opportunities in life are different as women. "We know that girls who strongly adhere to female gender stereotypes feel like they cannot do some things," Coyne said, "They are not as confident that they can do well in math and science. They do not like getting dirty, so they are less likely to try and experiment with things" [10].

One of the most harmful effects in Disney's stereotypes on girls is the body image. Unrealistic and ideal representations of the female body and beauty, such as small waists, large breasts, big eyes, and batting eyelashes, permeate Disney princess animated films, indicating a society in which physical beauty is highly valued. Many young girls are identified with fairy-tale princesses, who are always described as exceedingly beautiful, thereby wishing to imitate their ideal representations of beauty [11]. "Disney Princesses represent some of the first examples of exposure to the thin ideal," said researcher Sarah M. Coyne, "As women, we get it our whole lives, and it really does start at the Disney Princess level, at age three and four" [10]. Coyne's study showed that girls, who interacted the most with Disney princesses, showed worse self esteem about their bodies as time went on. Poor body image is a serious problem among young girls and can be a major precursor for developing an eating disorder later in life.

\subsubsection{Impact on public opinion}

What is more, stereotypes in Disney films can have severe effects on the young viewers. The stereotypes shown in Disney princesses themself and have been proved by many researchers to be physically and psychologically harmful to female viewers. For instance, at that time, stereotypes in Disney films might have impeded the development of feminism movement. As the core point of feminism movement is to encourage women live independently and keep individual style, Disney conveyed relatively opposite message and brought misunderstanding to the people at that time. Therefore, as the society is becoming more aware and supportive of body positivity, cultures and the LGBTQ community, it is necessary for Disney to pay more attention to change their concepts on stereotypes. The next step for Disney is to embrace this new and open minded world and include characters with varieties in order to have a better effect on their young viewers.

\section{A CHANGE TOWARDS FEMINISM}

With the changes of the times and the victory of the second wave of world feminism, Disney's female characters also changed. The characteristics of independent and courageous women are becoming more and more popular in the society, which also means that the mainstream views of society have changed. In 1998, Disney released the film Mulan, which changed the portrayal of a female protagonist. Hua Mulan abolishes female gender stereotypes and has more masculine characters than feminine [3]. Throughout the film, 
Mulan tries to become a "man", training intensely with her fellow soldiers and in the end, Mulan overpowers her male colleagues and defeat the Hans with her wit [12]. During the final battle, Mulan embraces her femininity and defeats the main antagonist not by pretending to be a man, but by being herself. This move promoted the message that there is strength in femininity, and females do not and should not need to forego their personality and behavior to gain agency [12]. The film shows young girls that they are just as capable as men and remind women today to fight and refuse rather than being silent.

With the release of Brave in 2012, Disney once again created a groundbreaking film for femininity. Brave tells the story of Princess Merida, who fights against her "faith" to be married and fights for herself in marriage, defying all gender expectations of society. The story follows Merida and her development with her family and herself. By labeling Merida as a true hero, not a dependent female counterpart, it is an endorsing change through the power of suggestion [4]. Merida's character specifically speaks to the teens of the $21 \mathrm{st}$ century by being rebellious, blaming everything on her mother, meanwhile being lost and alienated. The idea of beauty and perfection is not important to Merida, as being yourself is more important. It can be seen in her messy hair, which her mother often berated, and her ragged dress and athletic build. The fact that Merida does not marry and her statement that she may never marry, shows the young girls of the century have options and it reminds them that it is reasonable if a woman chooses not to marry. Children could learn that their lives are various and women have different characteristics, not just one stereotyped version of womanhood [13]. Similarly, the next film, Frozen, shows the love between two sisters instead of the princess and the prince. Same as Brave, Disney is showing audiences that women can be in control of their own destinies. Frozen performs better because it not only makes 1.28 billion USD in the box office worldwide, but also keeps a popular cultural phenomenon even after seven years of its release. Frozen was able to spread the message of feminism, independence, and the love of family to billions of people everywhere. Brave and Frozen tells the growth of main characters and through the development of their stories, it is clear to see they are discovering themselves and realizing their self reconciliation. For nearly a decade, Disney's characters are not limited to pure gender characters, but are more various with embodiment of the complexity of female personality, which can not be summed up by simple characteristics. They are all vivid with humanistic characters.

The 2021 film Raya and the Last Dragon took another big step by taking place around the world, which are filled with physically and intellectually powerful women with high and influential social statuses. They show strength and prowess of each female character. In addition, each female character is given their own beliefs, characteristics, and flaws. The story develops with their growth and changes, and finally they become heroes in their world. Not only are there so many women in places of power, but also they are never questioned or brought up. There are no backstories presented about women, having to rise up against a patriarchal society to claim these positions or having to fight to keep them. Instead, women are simply allowed to be chiefs, generals, warriors, and whatever else they choose to be. In this way, Raya and the Last Dragon normalizes the idea of female leadership and female warriors. Raya and the Last Dragon displays strong feminist themes, whereas previous Disney movies rights their feminist views on the surface, practically yelling it at the viewers through constant reminders that almost feel forced. Characters in Raya and the Last Dragon all get to be amazingly independent, unique, and strong. They also break female stereotypes through the designs of each character, as they are no longer impossibly thin, have bulging eyes, tiny noses, and long blond hair. The girls are sculpted with unique, short, half cut hair, imperfect noses, and different heights. In this film, Disney shows that they are slowly breaking through their old school stereotypical looks, and presenting healthier, more relatable characters that will have created a positive effect on children.

\section{CONCLUSION}

Disney has been around for over 80 years, during which time they have played a role in changing how society displays gender roles. It has produced a huge impact for kids as well as adults and it is a company that creates boundless, beautiful worlds. Although having gone through a rocky start filled with subtly anti feminist films with undesirable messages, Disney has proved itself to be one of the companies to impact and support feminism throughout the years. Disney made several breakthroughs in their films such as Mulan, which features the first female protagonist to not need a male companion; Brave and Frozen, which smashed through gender stereotypes, and the latest film Raya and the Last Dragon. Through this article, it can be seen that Disney has developed and changed a lot, going from submissive females to independent and powerful queens. What is more, as Disney itself grows, the world also changed with it. However, Disney is far from perfect. Disney still has a long way to go for their lack of female characters with different body types, cultures, and genders. In the future, Disney will continue to release more films to spread their message of feminism across the globe. 


\section{AUTHORS' CONTRIBUTIONS}

The author finished this through reading literature review as well as analyzing, and writing this paper individually.

\section{ACKNOWLEDGMENTS}

First and foremost, I would like to show my deepest gratitude to my teachers, who have provided me with valuable guidance in every stage of the writing of this thesis. Further, I would like to thank my parents for their encouragement and support. Without all their enlightening instruction and impressive kindness, I could not have completed my thesis.

\section{REFERENCES}

[1] Jones, Amani. "Disney Animation Has Gone Through 9 Phases, And I'm Here For ALL Of Them." Odyssey, 3 Aug. 2020.

[2] Barber, McKenzie. Disney's Female Gender Roles: The Change of Modern Culture. Indiana State University, MA thesis. 2015.

[3] Ebert, Roger. "The Little Mermaid." Roger Ebert, 17 Nov. 1989.

[4] Garabedian, Juliana. "Animating Gender Roles: How Disney is Redefining the Modern Princess." James Madison University. 2015.

[5] Yerby, A., Baron, S., Lee, Y. (n. d.) Gender Roles in Disney Animation. 2015. Retrieved from http://www.american.edu/soc/film/upload/genderroles-in-disney.pdf

[6] Fairman, Laura. "Influence And Appreciation Of Film In Today's Society." Rife Magazine, 2008.

[7] Charlotte R. Pennington,* Derek Heim, Andrew R. Levy, Derek T. Larkinm, Twenty Years of Stereotype Threat Research: A Review of Psychological Mediators, PMC, 2016 Jan 11.

[8] Steve Stroessner, Catherine Good, STEREOTYPE THREAT: AN OVERVIEW. 2011.

[9] Steven J. Spencer, Claude M. Steele, Diane M. Quinn, Stereotype Threat and Women's Math Performance, Journal of Experimental Social Psychology, Volume 35, Issue 1, 1999, pp. 4-28.

[10] Sarah Coyne, Eric Rasmussen, David A Nelson, Pretty as a Princess: Longitudinal Effects of Engagement With Disney Princesses on Gender Stereotypes, Body Esteem, and Prosocial Behavior in Children, Society in Research for Child Development, June 2016.
[11] Ashley Bispo, Fairytale Dreams: Disney Princesses' Effect on Young Girls' Self-Images, 2015.

[12] Sulistia, Retno. "Female Masculinity of Fa Mulan and its Impact towards her Relationship with Male Characters in Disney Movie Mulan." State University of Surabaya. 2016.

[13] Cook, P., \& Smelik, A. Feminist Film Theory. The cinema book (2nd ed.) London: BFI Pub. 1999. 